\title{
Annual and transient signatures of gas exchange and transport in the Castañar de Ibor cave (Spain)
}

\author{
Angel Fernandez-Cortes ${ }^{1}$, Sergio Sanchez-Moral ${ }^{2}$, Soledad Cuezva ${ }^{2}$, Juan Carlos \\ Cañaveras ${ }^{1}$, Rafael Abella ${ }^{3}$
}

\begin{abstract}
:
Fernandez-Cortes A., Sanchez-Moral S., Cuezva S., Cañaveras J.C. and Abella R. 2009. Annual and transient signatures of gas exchange and transport in the Castañar de Ibor cave (Spain). International Journal of Speleology, 38(2), 153-162. Bologna (Italy). ISSN $0392-6672$.

The large microclimatic stability is a basic characteristic of the subterranean karst systems and causes a high sensitivity to changes in environmental conditions. High-accuracy monitoring of Castañar de Ibor cave (Spain) determined the temporal evolution of the aerodynamic processes and ventilation rate by tracking $\mathrm{CO}_{2}$ and ${ }^{222} \mathrm{Rn}$ levels over a twelve-month period. This cave is characterized by a very stable microclimate, with high and relatively constant radon content (the mean value is $32200 \mathrm{~Bq} / \mathrm{m}^{3}$, roughly, and the standard deviation is $7600 \mathrm{~Bq} / \mathrm{m}^{3}$ ) and a moderate and quite stable $\mathrm{CO}_{2}$ concentration (the mean value is $3730 \mathrm{ppm}$ and the standard deviation is $250 \mathrm{ppm}$ ). Beside the general patterns of cave microclimate throughout an annual cycle, some particular microclimatic processes are described with regard to the gas exchange between the cave and the outside atmosphere. There is a complex microclimatic functional relationship between the meteorological and cave microclimate conditions and the diffusion and flow of tracer gases from the fractures and the pore system of soil and host rock to cave atmosphere. Transient variations of tracer gas on cave air are controlled by natural barometric fluxes and anthropogenic forced ventilation due to uncontrolled opening of cave entrance. The short-term fluctuations of gas levels on cave air reveal distinct patterns during the exhalation process of theses gases from the net of fissures and pores to the cave atmosphere, depending on the isolation effect of soil and host rock.
\end{abstract}

Keywords: Carbon dioxide, radon, cave aerodynamics, microclimatic monitoring, karst..

Received 11 February 2009; Revised 1 April 2009; Accepted 21 May 2009

\section{INTRODUCTION}

The gases ${ }^{222} \mathrm{Rn}$ and $\mathrm{CO}_{2}$ can be used as tracers for ventilation studies in caves (Bourges et al., 2001 and 2006; Fernandez-Cortes et al., 2006; Batiot-Guilhe et al., 2007), tunnels and underground quarries (Perrier et al., 2004 and 2007), because their concentrations depend largely on microclimatic variations within the cave and on the mass and energy transfer between cave, epikarst and soils, all of which are controlled by external climatic changes. Other tracer gas monitoring studies in isolated caves (Hoyos et al., 1998; Kowalski et al., 2008) have revealed a more complex process of mass and energy transfer within a

1. Dep. Ciencias de la Tierra y del Medio Ambiente - Lab. Petrología Aplicada, Universidad de Alicante, Ctra San Vicente del Raspeig s/n, San Vicente del Raspeig - Alicante, 03690, spain. acortes@ua.es, jc.canaveras@ua.es

2. Dep. Geología, Museo Nacional de Ciencias Naturales (CSIC), c/José Gutierrez Abascal, 2, Madrid, 28006, Spain. ssmilk@mncn.csic.es, scuezva@mncn.csic.es

3. Instituto Geográfico Nacional (IGN), c/Alfonso XII, Madrid, 328014, Spain.rabella@fomento.es karstic subterranean environment, as a function of the water saturation state of the double membrane system (host rock and soil) covering the cave atmosphere. Spatiotemporal distribution of tracer gases is related to cave morphology and the circulation of the air, and its evolution is correlated with microclimatic processes, such as (Faimon et al., 2006): 1) diffusion from epikarst, 2) degassing of dripwaters, 3) cave organic matter decomposition, 4) anthropogenic flux by breathing, 5) gas depletion controlled by ventilation, depending on cave geometry and microclimatic relationships between the cave and the outside atmosphere (air temperature and barometric pressure) and, in some cases, 6) on endogenous processes such as volcanism or magmatism.

Moreover, carbon dioxide is a key component controlling carbonate karst processes like limestone dissolution and speleothem growth, which are controlled by differences in the $\mathrm{CO}_{2}$ partial pressure in the water of the upper epikarst relative to cave atmosphere. Understanding the behavior of $\mathrm{CO}_{2}$ in caves is therefore critical for the preservation of rock painting sites (Sanchez-Moral et al., 1999) and show caves highly decorated with speleothems. On the other hand, understanding $\mathrm{CO}_{2}$ distribution and dynamics 
in caves is important for palaeoclimate research using stalagmites because their growth rates partially depend on cave atmosphere $\mathrm{pCO}_{2}$ (Spötl et al., 2005; Fairchild \& McMillan, 2007; Baldini et al., 2008). Radon in caves is of interest because concentrations may sometimes reach levels hazardous to human health (Hakl et al., 1997; Craven \& Smit, 2006). Therefore, radon monitoring is essential for providing the managers of show caves with some instruments to comply with the domestic legal requirements and to establish the suitable regime of visits.

The present paper focuses on the aerodynamics of a cave with a high environmental stability (Castañar de Ibor, Spain) with special attention to the physical mechanisms controlling the short-term fluctuations of tracer gas levels on cave air due to anthropogenic causes. In order to ensure the constant climate required for the conservation of caves, the application of the knowledge regarding mass and energy fluxes involved in the subterranean environments is also discussed.

\section{FIELD SITE}

Castañar de Ibor (Cáceres, Spain) is a cave formed by dissolution of dolomite strata interbedded in shales and greywackes of Precambrian Age with a particular variety of calcitic and aragonitic speleothems and also moonmilk deposits composed of huntite, dolomite and hydromagnesite (Alonso-Zarza \& Martin-Perez, 2008). The cave has a single artificial entrance built by reexcavation of a natural pit. Currently this vertical access is $9 \mathrm{~m}$ long over an area of $1.5 \mathrm{~m}^{2}$, connecting with the rest of the cave

Since its declaration as a Natural Monument in 1997, Castañar cave has limited visitation (i.e: 1508 persons during the year 2004, distributed among 189 groups). The monthly average of the number of visitors during 2004 was 126 people, distributed in groups with a maximum of 15 people. Each group stayed between 80 and 100 minutes inside the cave. The visitation route does not reach the Sala Lagos chamber (Fig. 1). A detailed record of visits (number of visitors, length of stay and duration of door opening during visits) was supplied by cave managers and guides.

\section{METHODS}

\section{Instrumentation}

A micro-environmental monitoring system was installed to record the microclimate at three locations: 1) outside the cave entrance, 2) the Nevada chamber and 3) the Lagos chamber (Fig.1). The microclimatic parameters measured within the cave were: temperature, relative humidity and carbon dioxide content of the air in both chambers, and air pressure and radon content only in Nevada chamber. Measurements were taken at $50 \mathrm{~cm}$ from the cave ceiling and in the middle of each chamber (roughly at 5-10 meters from the cave walls). Interior stations recorded every $10 \mathrm{~min}$ from December 2003 to December 2004, while the exterior monitoring station recorded hourly measurements throughout the study period. The network of monitoring stations consists of a datalogger (dataTaker DT50, Grant Instruments Ltd.,
Cambridge, UK) accepting voltage and current inputs from a 16-channel multiplexer with special sensors designed for the narrow range of measurements expected. The outdoor weather station includes a tipping-bucket rain gauge for rainfall measurements and sensors for relative humidity and air temperature (HOBO Weather Station). Cave air $\mathrm{CO}_{2}$ concentrations were measured using a dual wavelength infrared absorption sensor (non-dispersive infrared technology, model 8102, Ventostat) over the range $0-7000 \mathrm{ppm}$, with an accuracy of $7 \%$ or $\pm 75 \mathrm{ppm}$. Temperature and relative humidity of the air were measured by a Rotronic $\square$ humidity and temperature probe HygroClip S3, which combines a Pt100 1/3 DIN temperature sensor (measuring range -40 to $60{ }^{\circ} \mathrm{C}$ and accuracy $\pm 0.2{ }^{\circ} \mathrm{C}$ (at $23 \pm 5{ }^{\circ} \mathrm{C}$ ) and a capacitive sensor (measuring range 0 to $100 \% \mathrm{RH}$ and accuracy $\pm 0.6 \%$ ). Air pressure was measured by a Vaisala BAROCAP silicon capacitive, absolute pressure sensor with an accuracy of $\pm 0,1$ mbar (measuring range 800 to 1100 mbar).

Differences of air temperature and $\mathrm{CO}_{2}$ concentration between sensors were previously checked in the laboratory by measuring all of them in the same point during a long inter-calibration period, in order to ensure a proper measurement of these parameters and readjustment of the time series data obtained within the cave. This procedure was carried out at the beginning and end of the study. Besides, a thermistor sensor (model 5611T, Hart Scientific) was used for periodic calibration (in situ) of temperature sensors, with an accuracy of $\pm 0.015^{\circ} \mathrm{C}$ within the temperature range $0-100{ }^{\circ} \mathrm{C}$ and a digital resolution of $0.001{ }^{\circ} \mathrm{C}$. The temperature sensor was connected with a $10 \mathrm{~m}-$ long cable to a handle device for data reading (model 1521, Hart Scientific). In addition, a dual-wavelength infrared absorption sensor (non-dispersive infrared technology) was used for periodic calibration (in situ) of sensors installed within the cave. The human influence on the readings during the periodic calibrations was minimized by leaving the hand-held sensors without human presence during one hour at each point, in order to get a complete adaptation to the environment of the cave. Data acquisition was carried out quickly by a single person to minimize human influence on the microclimate. The calibration test showed that this influence was clearly minimal, as the increase of both parameters was lesser than the resolution of the sensors.

Finally, the ${ }^{222} \mathrm{Rn}$ concentration was measured at Nevada chamber by means of a Pylon AB5 scintillatorphotomultiplier based sensor, which functions as a continuous passive radon detector (CPRD). This radon detector has maximum counting rate of 10000 cps, with a lowest activity detectable of $24.8 \mathrm{~Bq} / \mathrm{m}^{3}$, a sensitivity of $0.041 \mathrm{cpm} / \mathrm{Bq} / \mathrm{m}^{3}$ and an accuracy of $\pm 4 \%$ (operating temperature: -5 to $+50{ }^{\circ} \mathrm{C}$ ). The nominal background is $0.4 \mathrm{cpm}$ when tuned for optimum performance to measure low levels of radon activity. This equipment was calibrated periodically with a ${ }^{222} \mathrm{Rn}$ calibration standard cell model Pylon 3150 and RNC standard radioactive sources of known activity concentration (Dinh-Chau et al., 2005). 


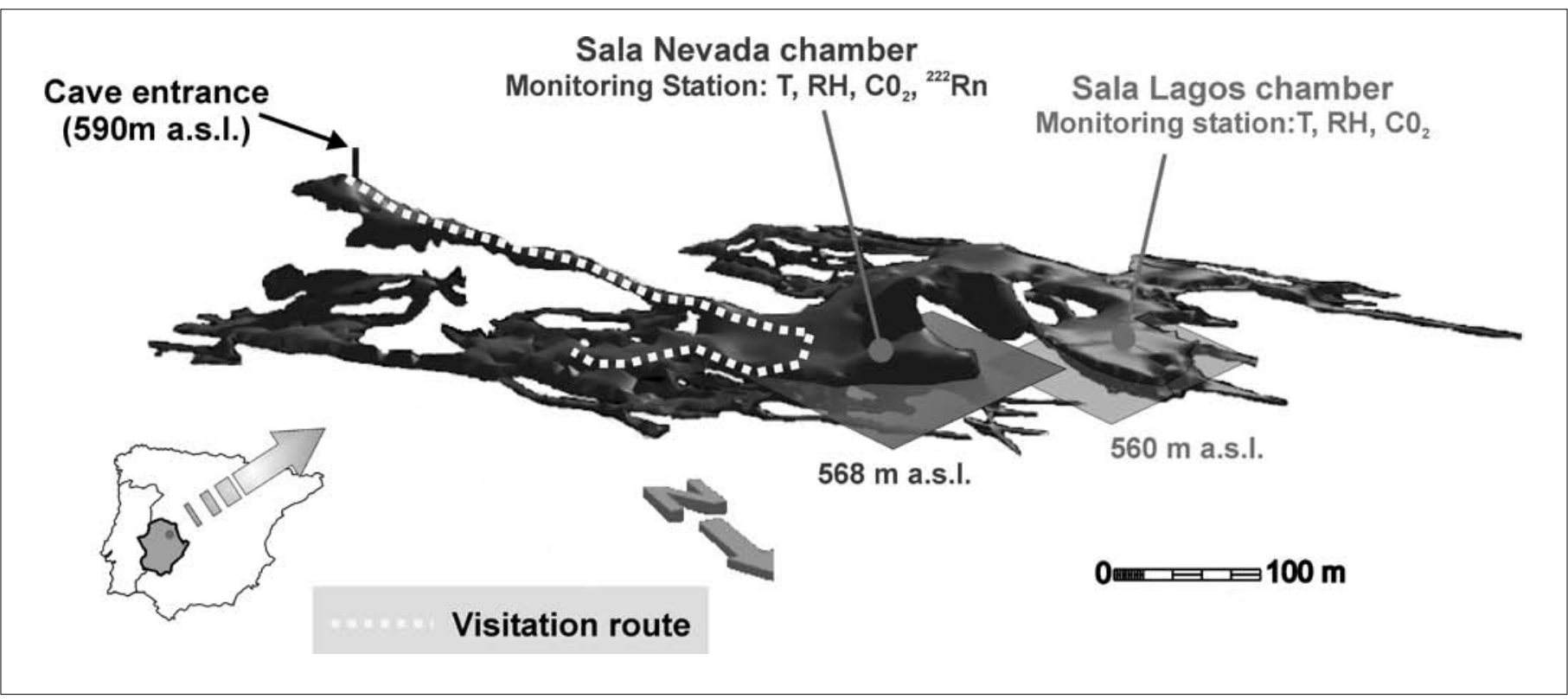

Fig.1. 3-D view of Castañar de Íbor cave showing spatial distribution of the environmental monitoring stations and depth location of the main areas.

\section{Air density calculations}

Air density is a key parameter for the study of cave aerodynamics and it is a factor determining the behavior of the internal atmosphere and the degree of gas connection between the subterranean environment and the outside atmosphere. The difference in density between the air inside the cave and outside governs the movement (convective flow) and direction of air flow (Choppy, 1990; Cigna, 2004). Besides factors such as temperature and pressure, air density is also determined by the compositional features of the subterranean karstic atmosphere; water vapor and $\mathrm{CO}_{2}$ concentration, which reaches high values within these environments. Unlike humidity, a significant increase in the proportion of $\mathrm{CO}_{2}$, whose molecular weight is $44.01 \mathrm{~g} / \mathrm{mol}$, would lead to an increase in the density of air under equal conditions of pressure and temperature. A general expression for calculating the density of humid air is based on the equation of state of a mixture of dry air and water vapor (equivalent equations were implemented by Badino, 1995 and Massen et al., 1998):

$\rho_{\text {humid air }}=\left(\mathrm{pM}_{\mathrm{a}} / \mathrm{RT}\right) \cdot\left[1-\left((1-\varepsilon) \cdot\left(\mathrm{RH} \cdot \mathrm{p}_{\mathrm{vs}} / 100 \mathrm{p}\right)\right)\right]$

where: $\mathrm{p}$ is atmospheric pressure $(\mathrm{atm}), \mathrm{M}_{\mathrm{a}}$ is the molecular weight of dry air $(28.97 \mathrm{~g} / \mathrm{mol}), \varepsilon$ is the relationship between the molecular weights of water vapor and dry air (0.62201), considering the standard atmosphere with a molar fraction of $\mathrm{CO}_{2}$ of 0.00035 (CRC, 2003), $\mathrm{R}$ is the universal constant for a mole of ideal gas $\left(0.08206 \mathrm{~L} \cdot \mathrm{atm} \cdot \mathrm{mol}^{-1} \cdot \mathrm{K}^{-1}\right)$, $\mathrm{T}$ is air temperature $(\mathrm{K}), \mathrm{RH}$ is relative humidity (\%) and $\mathrm{p}_{\mathrm{vs}}$ is saturation vapor pressure (in atm, based on Buck, 1981).

\section{RESULTS}

\section{Prevailing microclimatic conditions}

Castañar de Ibor cave has a stable microclimate throughout the year and a low energy exchange with the outside, with constant relative humidity values near saturation. Thus, the maximum temperature variations in the year 2004 were $0.16^{\circ} \mathrm{C}$ in the Nevada chamber and $0.15{ }^{\circ} \mathrm{C}$ in the Lagos chamber. The mean value of the temperature and $\mathrm{CO}_{2}$ air concentration is $16.95( \pm 0.002){ }^{\circ} \mathrm{C}$ and $3685( \pm 6) \mathrm{ppm}$, respectively, in the Nevada chamber, whereas in Lagos chamber the mean values are $16.97( \pm 0.001){ }^{\circ} \mathrm{C}$ and 3767 $( \pm 3) \mathrm{ppm}$, respectively. The annual amplitude for the $\mathrm{CO}_{2}$ levels of air is $1300 \mathrm{ppm}$ in both chambers. The subterranean atmosphere of Castañar cave has a very high level of ${ }^{222} \mathrm{Rn}$ (annual average of $32246 \mathrm{~Bq} /$ $\mathrm{m}^{3}$ ), with monthly mean values always higher than $20000 \mathrm{~Bq} / \mathrm{m}^{3}$. The annual amplitude for the ${ }^{222} \mathrm{Rn}$ content is $30730 \mathrm{~Bq} / \mathrm{m}^{3}$. Consequently, some effective management measures were applied to reduce the ${ }^{222} \mathrm{Rn}$ levels in the cave atmosphere during visits in order to prevent the guides from being exposed to higher than recommended doses of radiation (Lario et al., 2006). The relative humidity of the cave is also very stable, showing a constant state of saturation (> 99.5\%).

Despite the prevailing high thermo-hygrometric stability registered in Castañar cave, a stair-step pattern with strong seasonal shifts is distinguishable (Fig. 2), especially in terms of tracer gas levels $\left(\mathrm{CO}_{2}\right.$ and ${ }^{222} \mathrm{Rn}$ ). Thus, during late May and throughout the summer (from June to October) the dry weather conditions favor the air exchange between the cave and the outside atmosphere through the membranes covering the cave (host rock and soil). From OctoberNovember a phase of gaseous recharge is detected, coinciding when: 1) the outside temperature drops below the cave temperature, 2) the external relative humidity increases and 3) the first events of intense rain are registered (Fernandez-Cortes et al., 2009).

\section{Cave air stratification}

There is an air-stratification phenomenon during summer, contemporary to the phase of underground air renewal. Thus, the colder, denser and $\mathrm{CO}_{2}-$ enriched air tends to move toward the deepest areas of the cave across a density gradient (Fig. 2). With regard to $\mathrm{CO}_{2}$ levels a brief time-gap (36 hours long) is 


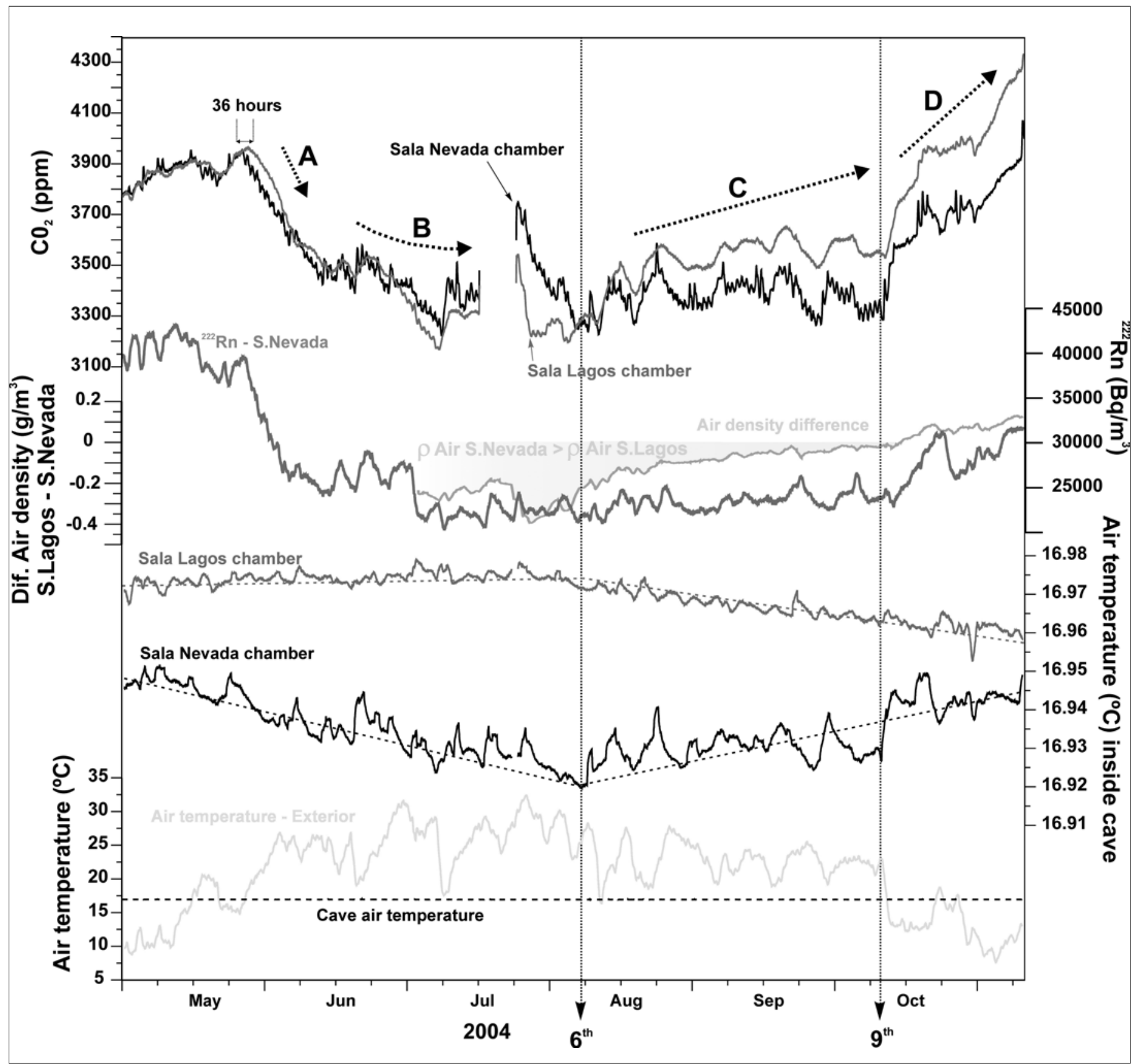

Fig.2. Time series (daily smoothed data) of air temperature (exterior and inside cave), air density, ${ }^{222} \mathrm{Rn}$ level and $\mathrm{CO}_{2}$ content of air within both chambers, from May to first days of November 2004 (underground air renewal: period throughout the external air temperature exceeds the cave air temperature). Several microclimatic processes are detected (see text); A: Beginning of the "cave degasification"; B: Partial stratification process in Sala Nevada chamber detected by an accumulation of $\mathrm{CO}_{2}$-enriched and colder air; $\mathrm{C} ; \mathrm{CO}_{2}$ diffusion to S.Lagos from S.Nevada and seepage water, provoking a continuous increase of air density in S.Lagos (from 6 August 2004 there is a change of slope (dotted lines) on both air temperatures and $\mathrm{CO}_{2}$ level in Sala Lagos exceeds the gas level in Sala Nevada), and D; Global stratification of cave atmosphere including Sala Lagos chamber coinciding with the beginning of gas recharge phase.

detected between the beginning of "cave degasification" process and the response of $\mathrm{CO}_{2}$ content of air in Lagos chamber.

Air temperature in Lagos remains higher than air temperature in Nevada chamber, which decreases from May to June (Fig. 2) revealing the external influence of winter weather on the air temperature in Nevada chamber, after several months delay. During this period the mean air temperature gradient $\left(\mathrm{T}_{\text {ext }}{ }^{-}\right.$ $\mathrm{T}_{\text {cave air }}$ ) oscillates from $+7.97^{\circ} \mathrm{C}$, for Nevada chamber, to $+7.92{ }^{\circ} \mathrm{C}$ for Lagos chamber, and the difference of air density (Lagos - Nevada) reaches the highest values (between -0.2 and $-0.4 \mathrm{~g} / \mathrm{m}^{3}$ ). The subtle difference in air temperature between both chambers (in terms of thermal gradient) is more noteworthy during the first period of summer (June-July). Despite these favorable thermo-density conditions for air mass movement between both chambers, however a convective circulation was not detected. Although the Lagos chamber is only located approximately 5 meters below Sala Nevada chamber, the special surface morphology between both chambers (with high ascending slopes of blocks and flowstones; see Fig. 1) prevent a direct physical connection. Therefore, the air mass stratification is firstly noticeable in Nevada chamber relative to the cave entrance and more 
external galleries, accumulating colder, denser and $\mathrm{CO}_{2}$-enriched air in this area of the cave (a downward trend of air temperature whereas the $\mathrm{CO}_{2}$ exceeds the gas level in Lagos chamber).

From 6 August 2004 there is a change of slope in both air temperatures (dotted lines, in Fig. 2), revealing the start of an external influence of summer weather on the air temperature in Nevada chamber. On the contrary, air temperature in Lagos chamber decreases slightly $\left(-0.015{ }^{\circ} \mathrm{C}\right)$ coinciding with the likely rise of relative humidity by the continuous drip rate in this active area. In terms of infiltration process, some short-time rainfalls were registered during August $\left(59 \mathrm{~L} / \mathrm{m}^{2}\right.$, as opposed to 4 $\mathrm{L} / \mathrm{m}^{2}$ registered during July). Air temperature in Lagos chamber begins to fall with a certain delay (roughly 89 days later). The increase of air temperature in Nevada chamber (Fig. 2) corresponds to a conventional model for summer months, consisting in a downward heat by diffusion of vapor water (from the outside atmosphere to cave). Simultaneously the $\mathrm{CO}_{2}$ level in Lagos chamber exceeds the gas concentration in Nevada chamber, and remains higher throughout the winter season. The remarkable $\mathrm{CO}_{2}$ rise observed in the atmosphere of Lagos chamber is caused by two processes: 1) gas accumulation after the previous slight $\mathrm{CO}_{2}$ diffusion from Nevada chamber to Lagos chamber during July and first days of August (the average content of $\mathrm{CO}_{2}$ is 3420 ppm in Nevada chamber, higher than the average content of $\mathrm{CO}_{2}, 3280 \mathrm{ppm}$, in Lagos chamber), and, especially, 2) $\mathrm{CO}_{2}$ degassing from the seepage water. The air temperature fall and the $\mathrm{CO}_{2}$ accumulation determine a constant increase of air density within Lagos chamber, reversing the difference of air density between both chambers from $9^{\text {th }}$ October (Fig. 2).

If the air stratification process remains over time, the denser and colder air mass gains height in Sala Nevada chamber surpassing the morphological barriers between both chambers and descending toward Lagos chamber. Finally, Sala Lagos chamber ends up being affected by the accumulation of $\mathrm{CO}_{2}-$ enriched air along a density gradient. From 9 October 2004 the cave air temperature is constantly higher than outside air and the air density of Lagos chamber is permanently higher than at Nevada chamber. From this date, a short-term fall in exterior air temperature is registered tending to match the cave air temperature and the external relative humidity increases, which provokes the water saturation of the soil and most superficial layers of the host rock due to a reduced evapotranspiration. This fact is detected by an upward trend of $\mathrm{CO}_{2}$ and ${ }^{222} \mathrm{Rn}$ levels, revealing the isolation of the cave atmosphere by blocking permeability.

\section{TRANSIENT SIGNATURES OF TRACER GASES} Local movement of tracer gases and heat exchange

The air stratification process and the local movement of tracer gases and heat exchange within the cave allow explaining the increases in $\mathrm{CO}_{2}$ level and temperature of a non-visited part of the cave, such as Sala Lagos chamber. Fig. 3 shows one of the most severe microclimatic disturbances registered on 27 March 2004, because of the consecutive visits into the cave of three groups of 15 people during 3 $\mathrm{h}$ and $46 \mathrm{~min}$. The distance from sensors to people was variable but always greater than 10 meters. Air temperature rose up to $+0.06{ }^{\circ} \mathrm{C}$ in Sala Nevada chamber and a return to the previous conditions was only achieved approximately 22 hours later. This diffusive relaxation process of the thermal conditions of air in Nevada chamber was characterized by a downward trend of $0.002-0.003{ }^{\circ} \mathrm{C} /$ hour, roughly, once the third group of visitors left the cave. However, in Sala Lagos chamber the increase of air temperature was originated by heat transfer (conduction) and, to a lesser extent, by convective circulation, but it was not noticeable until 36 hours later by the way of a softly slope-break of air temperature series. The breathing of visitors in Sala Nevada chamber provokes the increase of air vapor pressure, and consequently of absolute humidity, above the level of this parameter in Sala Lagos chamber (Fig. 3). In spite of this change in the vapor pressure gradient, no increases of vapor content were detected in the atmosphere of Lagos chamber. This fact indicates a fast condensation process of vapor excess focalized in Nevada chamber, generating a punctual fall of air density (positive air density difference between both chambers) since this parameter decreases when vapor content rises into an air mass. In addition, the human presence provokes the increase of temperature by conduction. Thus, the equilibrium in the stratification process of the cave atmosphere is reached, compatible with a filling box mechanism modified by heat exchanges with the boundaries, as described by Crouzeix at al. (2006).

Subsequently, this vapor excess condenses on the rock surface (vapor pressure in Nevada chamber falls below Lagos chamber) and the prevailing air density differences are re-established. The $\mathrm{CO}_{2}$ content of air in Lagos chamber increases slightly by gas diffusion from the upper areas, caused by a remarkable imbalance of $\mathrm{pCO}_{2}$ in air between both chambers. This increase of $\mathrm{CO}_{2}$ content in Lagos chamber is noticeable $5 \mathrm{~h}$ and $30 \mathrm{~min}$ later than the fast increase of this tracer gas detected in Nevada chamber due to the direct exhalation of visitors. The conjunction of vapor condensation and moderate-high $\mathrm{CO}_{2}$ levels, even with punctual increases of this tracer gas in nonvisited areas, could activate the corrosion processes on the speleothem surfaces.

\section{Barometric control}

Time evolution of the tracer gases $\left(\mathrm{CO}_{2}\right.$ and $\left.{ }^{222} \mathrm{Rn}\right)$ and air pressure conditions is shown in Figure 4, relative to the intervals with visits to the cave. Both characteristics of visits are drawn: number of visitors and duration of door opening. Likewise, two different states of cave-exterior air exchange have been considered; dry period of underground air renewal (Fig. 4A) and wet period of gases recharge (Fig. 4B)

External pressure fluctuation is responsible for air movement in Castañar cave, especially when the air exchange through the net of fissures and pores is limited (isolated cave atmosphere from December to May). Whenever the pressure changes outside, air 


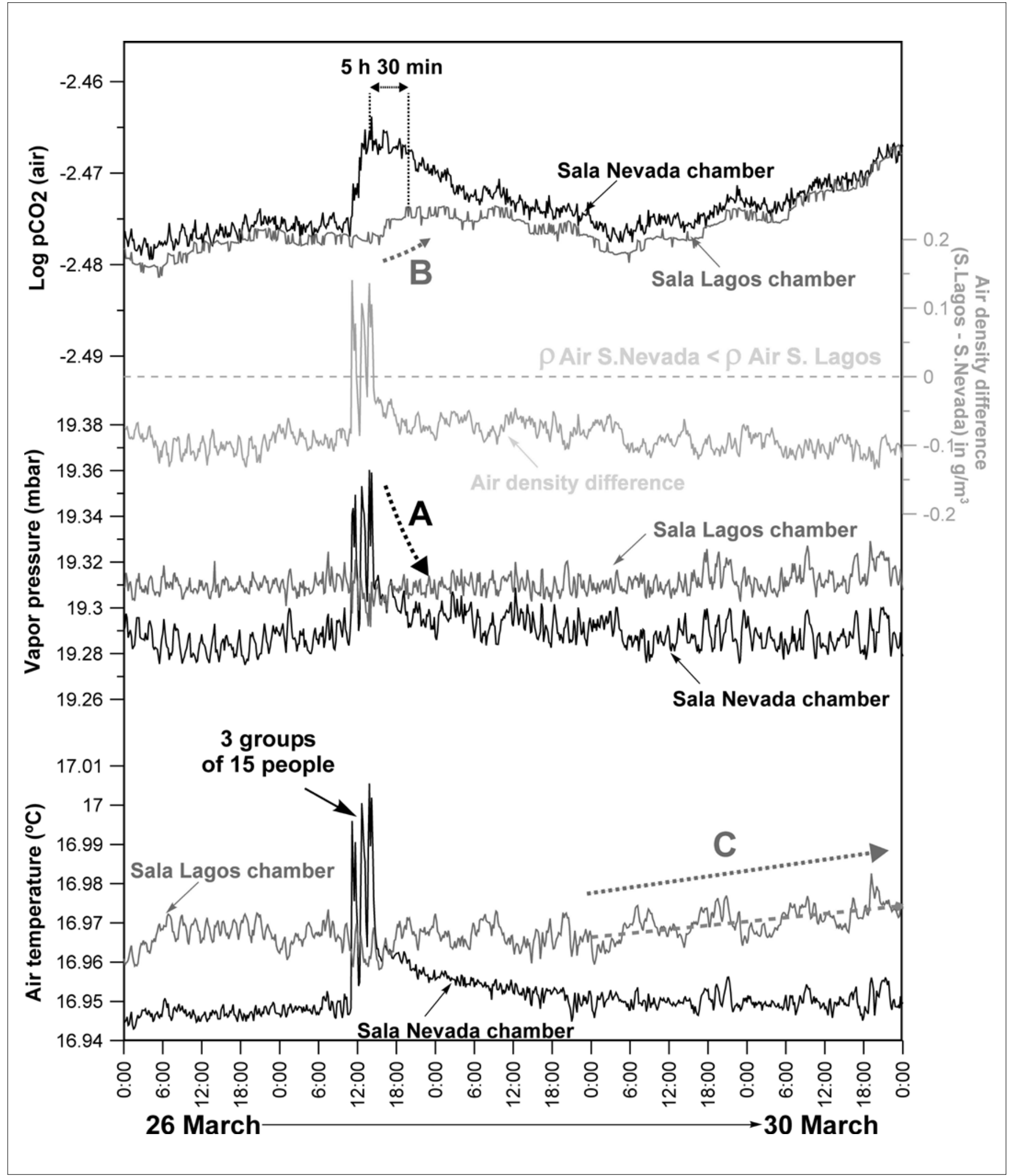

Fig.3. Detailed time series (time lag: $10 \mathrm{~min}$ ) of microclimatic conditions in Castañar cave during a visit of 45 people during 27 March 2004 . Several environmental impacts are distinguished (see text); A: fast condensation of vapor excess in Sala Nevada chamber, B: CO2 rise by gas diffusion once the prevailing air density differences are reestablished between both chambers, and C: disturbance of air temperature trend in Sala Lagos chamber because heat transfer by conduction.

will flow into or out of the cave to maintain pressure equilibrium. The cave/exterior air exchange takes place through the main discontinuities (fissures and fractures) near the cave entrance and, of course, through the quasi-hermetic trap door installed at the entrance. This kind of cave has been termed a 'breathing cave' and, normally involves periodic but not seasonal changes in direction of airflow. Normally the cave volume must be extremely large, such as Castañar cave, to give significant air movement by this mechanism. It is feasible to characterize the ventilation regime of a subterranean environment due 


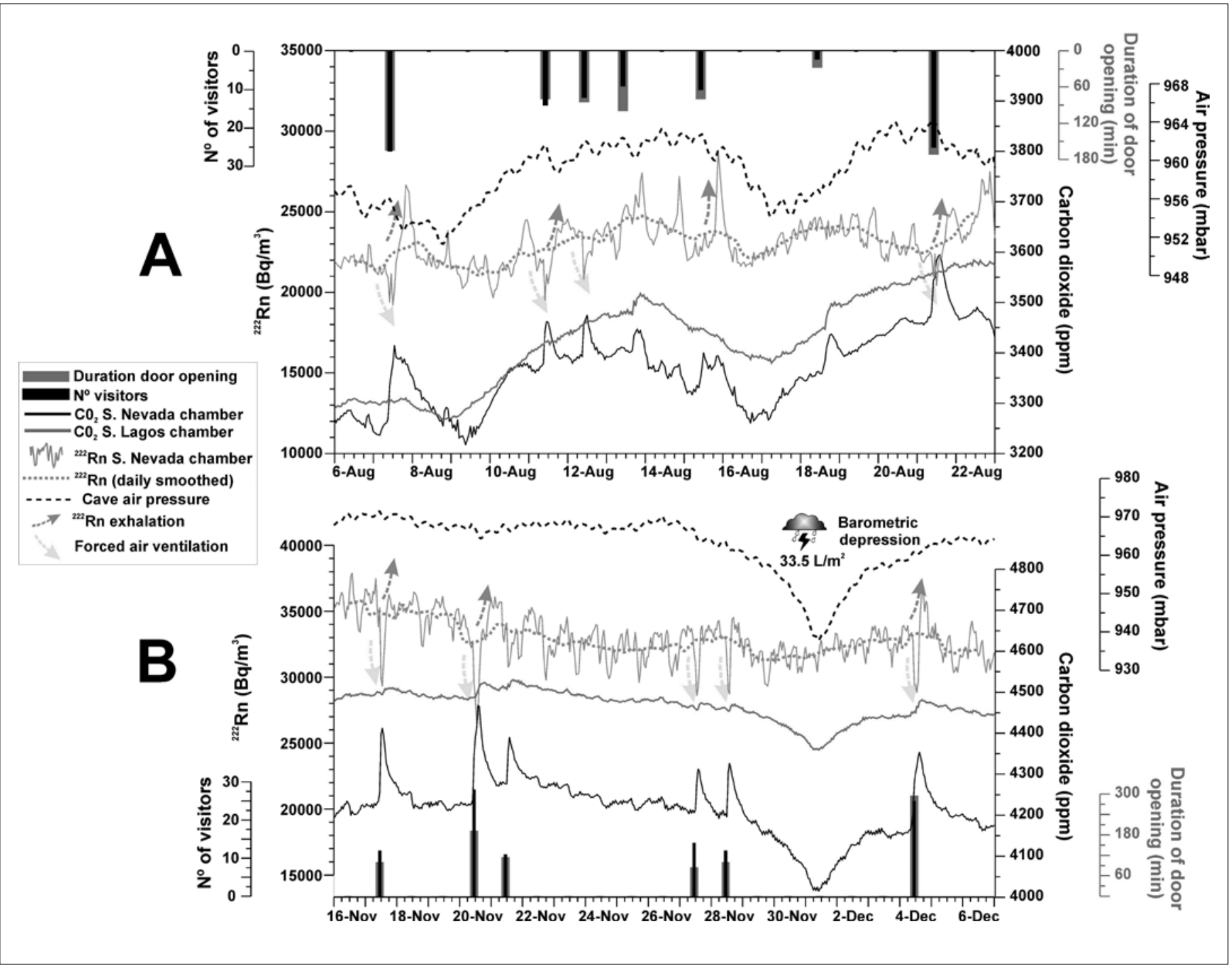

Fig.4. Functional relationship between the characteristics of visits (number of visitors and duration of door opening) and $\mathrm{CO}_{2}{ }^{222} \mathrm{Rn}$ levels during two different states of air exchange cave-exterior: A; dry period of underground air renewal, and B; wet period of gases recharge. Take note the different behavior of both tracer gases during the intervals of forced ventilation by door opening and throughout the prevailing conditions of barometric depression in weather.

to atmospheric pressure pumping, using a tracer gas (i.e.: ${ }^{222} \mathrm{Rn}$ gas, Perrier et al., 2004), or also estimating the volume of natural voids by a calculation based on outflow of air from a well connected to the void under constant atmospheric pressure (Massen et al., 1998).

The subterranean atmosphere of Castañar cave could behave as an air mass enclosed in a void under a small overpressure, and escaping slowly from that void through an opening; overpressure and outflow should continuously fall. This fact is clearly appreciable during periods with a limited air exchange cave-exterior through the covering membranes (soil and host rock) (Fig. 4B). Thus, the sharp fall of air pressure within the cave (-27 mbar in only 3 days), due to the prevailing conditions of barometric depression in weather towards the end of November and the first days of December 2004 (with intense rainfalls of $33.5 \mathrm{~L} / \mathrm{m}^{2}$ ), constrains the cave air outflow in order to achieve the barometric equilibrium. This fast air movement entails the simultaneous evacuation of $\mathrm{CO}_{2}$-enriched air from the cave and the inflow of outside air, reducing the $\mathrm{CO}_{2}$ level in both chambers $(-200$ ppm in Nevada chamber and -125 ppm in Lagos chamber) and, to a lesser extent, the ${ }^{222} \mathrm{Rn}$ content of air (roughly $-3500 \mathrm{~Bq} / \mathrm{m}^{3}$ ). A similar behavior between the cave air pressure and the tracer gas levels is also observed during the spring season or during the summer months (Fig. 4A). However, in these cases, the depletion of tracer gas levels by a "breathing cave" phenomenon is less obvious, since the air exchange between cave and exterior through the host rock and soil membranes is active. Thus, during these periods the atmospheric pressure-induced strain squeezes part of the contained fluids (air and water) of the network of fissures and pores into the cave by exhalation, generating a moderate rise of tracer gas concentration in cave atmosphere.

\section{Human-induced ventilation}

Cave air ventilation is forced during time-intervals with tourist visits due to the door opening, and as a function of barometric pressure differences between the exterior and the cave atmosphere. This effect is more marked when the cave air temperature is much higher than outside air, generating a convective air circulation along a thermo-density gradient, as well 
as when the degree of water saturation within soil and host rock membranes limits the air exchange through the cave entrance. In this sense, the forced ventilation process is favored during the period shown in Fig. 4A in relation to the period shown in Fig. 4B. Some natural daily periodicities on ${ }^{222} \mathrm{Rn}$ levels are also observed during periods without visits or opening of cave entrance (i.e: from 22 to 26 November 2004, Fig. 4B). In this sense, the significance of the $12 \mathrm{~h}$-barometric tides in the ${ }^{222} \mathrm{Rn}$ signal within subterranean environments has been previously documented. Some studies reveal a high sensitivity of radon exhalation flux from the soil and host rock to changes of atmospheric pressure (Richon et al., 2009) or due to increases of groundwater level which displaces the gas into the subterranean atmosphere (Barnet et al., 1997), being both processes caused by earth tides.

The different evolution of $\mathrm{CO}_{2}$ and ${ }^{222} \mathrm{Rn}$ levels during the short-periods of human-induced ventilation makes the distinctive genetic mechanism of each tracer gas clear. The $\mathrm{CO}_{2}$ content of cave atmosphere comes mainly from soil and the dissolution of the rest of dolomite strata interbedded in the host rock (shale and greywacke). Subsequently, once the infiltration water reaches the cave atmosphere (with a lower $\mathrm{pCO}_{2}$ ), a $\mathrm{CO}_{2}$-degassing process is generated. This process is associated to the precipitation of secondary minerals in the cave. The ${ }^{222} \mathrm{Rn}$ gas derives from the ${ }^{238} \mathrm{U}$ present within the host rock (which decays through several steps into ${ }^{226} \mathrm{Ra}$ and ${ }^{222} \mathrm{Rn}$ ). Both emanation and exhalation allow the radon movement to the cave atmosphere. The first step, or emanation, is the ${ }^{222} \mathrm{Rn}$ movement from the mineral grain to the porous system of the host rock, since when the alpha particle is ejected the ${ }^{222} \mathrm{Rn}$ atom is subjected to a recoil effect that dislodges the atom from the mineral lattice or molecule where ${ }^{226} \mathrm{Ra}$ disintegrated with distance ranges between 0.02 to 0.07 $\mu \mathrm{m}$ (Cigna, 2005). The second step is the exhalation process corresponding to the ${ }^{222} \mathrm{Rn}$ movement from the net of pores and fissures to the cave atmosphere.

The opening of the doors (tourist visits) provokes an air outflow until the barometric pressure equilibrium cave/exterior is achieved. During these periods a sharp fall of the ${ }^{222} \mathrm{Rn}$ content of air is registered, which is not detected in the $\mathrm{CO}_{2}$ levels (Fig. 4) because this tracer gas is replaced by the air trapped within the net of fissures and pores of the host rock (with a $\mathrm{CO}_{2}$ content similar to the cave atmosphere). As the cave evacuates tracer gas-enriched air by forced ventilation, the ${ }^{222} \mathrm{Rn}$ level drops quickly because although the exhalation from the more superficial pores of the host rock and speleothems is initially favored, the emanation process, however, is delayed due to the scarce porosity of the shale and greywacke. Thus, the ${ }^{222} \mathrm{Rn}$ drops are more evident (ranging from -3000 to $-7000 \mathrm{~Bq} / \mathrm{m}^{3}$ ) when the air exchange through the host rock and soil membranes, and therefore the ${ }^{222} \mathrm{Rn}$ exhalation, are limited due to the high degree of water saturation (Fig. $4 \mathrm{~B})$. On the contrary, during the periods with cave/ exterior air connection through the host rock and soil membranes the ${ }^{222} \mathrm{Rn}$ content doesn't fall more than
$-3000 \mathrm{~Bq} / \mathrm{m}^{3}$ (Fig. 4A).

Once the cave entrance is closed, ${ }^{222} \mathrm{Rn}$ concentrations rise again by exhalation from the net of fissures and pores to the cave atmosphere, until reaching an equilibrium concentration determined by the ${ }^{238} \mathrm{U}$ and ${ }^{226} \mathrm{Ra}$ present within the host rock and speleothems. ${ }^{222} \mathrm{Rn}$ exhalation is more intense (the increases range between +2000 and $+5000 \mathrm{~Bq} / \mathrm{m}^{3}$ ) when the air exchange between cave and exterior through the host rock and soil membranes is favored (Fig. 4A). Whereas the exhalation process is limited (about $+2000 \mathrm{~Bq} / \mathrm{m}^{3}$ ) during periods with a higher proportion of water within the net of fissures and pores that feed the cave (Fig. 4B). In short, the door opening during tourist visits provokes an imbalance between both phenomena (radon exhalation and radon drops due to the forced ventilation). Thus, the ${ }^{222} \mathrm{Rn}$ level is depleted by forced ventilation during the wet periods with a confined cave atmosphere, although the general pattern corresponds to an upward trend during these periods. On the contrary, this ventilation provokes some increases of ${ }^{222} \mathrm{Rn}$ due to the favored exhalation during the dry periods with an "open cave system", although the general pattern corresponds to a downward trend during these periods (cave degasification).

With regard to the $\mathrm{CO}_{2}$ level of air in Nevada chamber, a natural time-evolution in accordance with the behavior of $\mathrm{CO}_{2}$ in Lagos chamber (without tourist visits) is registered, except during the occasional visits which provoke daily fluctuation of gas level. The anthropogenic impact on the $\mathrm{CO}_{2}$ levels of cave air is slightly lower (about $+150 \mathrm{ppm}$ ) when air exchange between cave and exterior through the host rock and soil membranes is favored (Fig. 4A), whereas this impact is higher (between +150 and $250 \mathrm{ppm}$ ) when air exchange through the host rock and soil membranes is limited (Fig. 4B). Likewise, the recovery time of $\mathrm{CO}_{2}$ level after visits is lower than 12 hours in the first case, whereas this recovery time is delayed for one more day in the second case.

\section{IMPLICATIONS FOR A SUSTAINABLE CAVE MANAGEMENT AND SPELEOTHEMS CONSERVATION}

The unstability of $\mathrm{CO}_{2}$ levels in cave atmosphere due to the forced air ventilation by uncontrolled opening of the cave entrance, plays a key role from a speleogenetic point of view. In this sense, the sharp drop of $\mathrm{pCO}_{2}$ in the cave air due to forced ventilation during visits (prolonged opening of cave access) generates an imbalance between the $\mathrm{pCO}_{2}$ of seepage water, reaching the cave by slow flows, with respect to the subterranean atmosphere. The equilibrium is reestablished by $\mathrm{CO}_{2}$-degassing of seepage water. If the degassing process of seepage water is becoming more intense as a result of a continuous depletion of $\mathrm{CO}_{2}$ level in the cave atmosphere, it would alter the mineral deposition rates and the suitable conditions for speleothems growth. Although these conditions could be occasionally reached with the current configuration of the cave access, however it should not be increased or accelerated in time by improper management practices. 
Therefore, cave management efforts should be directed to maintain these environmental conditions and limit the time intervals during which the cave entrance is open for tourist visits. Conversely, elevated values of cave air $\mathrm{pCO}_{2}$ (for example, during visits under conditions of low gas exchange between the cave and the outer atmosphere) can inhibit the mineral deposition or, even provoke the beginning of condensation-corrosion processes.

\section{CONCLUSIONS}

The temporal pattern of tracer gases $\left(\mathrm{CO}_{2}\right.$ and $\left.{ }^{222} \mathrm{Rn}\right)$ in Castañar cave throughout an annual cycle reveals some complicated processes related to cave ventilation and gas exchange with outside air, controlled by hydrogeological, meteorological and microclimatic factors. The functional relationship between air pressure and levels of tracer gases shows more nuances than the simplified model described in other caves; decreasing cave atmosphere pressure increases ${ }^{222} \mathrm{Rn}$ levels (or $\mathrm{CO}_{2}$ levels) and vice versa (Hakl et al., 1996 and 1997, Denis et al., 2005). This is related with the forced ventilation through the cave entrances. Therefore, cave atmosphere pressure decreases are correlated with periods when the cave entrance is open (tourist visits). During rainy months and when air temperature outside is lower than the cave air temperature, a convective inflow of external air (colder and denser) is generated toward the cave atmosphere. During summer months the opening of the cave entrance provokes a barometric imbalance, entailing large-scale dilution and evacuation processes by air volume changes. In both cases the incoming air is comparatively depleted in $\mathrm{CO}_{2}$ and ${ }^{222} \mathrm{Rn}$, so the levels of tracer gases undergo a fast decrease. The different evolution of $\mathrm{CO}_{2}$ and ${ }^{222} \mathrm{Rn}$ levels during the short periods of forced ventilation makes clear the distinctive genetic mechanism of each tracer gas clear, especially when the degree of water saturation within soil and host rock membranes limits the air exchange through the cave entrance.

The evolution of $\mathrm{CO}_{2}$ and ${ }^{222} \mathrm{Rn}$ distribution in Castañar cave is also determined by a compartment behavior related with a geometric control of cave aerodynamics (Baldini et al., 2006), ensuring the confinement of the deepest part of the cave (Sala Lagos chamber). This fact is reflected in the delay of the environmental response to the beginning of the "cave degasification" and air mass stratification processes within this most isolated part of the cave, or even in the delay on the environmental response to the extra-contribution of $\mathrm{CO}_{2}$ by the visits of upper areas of the cave. Similar time-delay in the response to air stratification or ventilation processes has been observed in other subterranean environments under a karstic framework, which has enabled to define the confined character of a given cave, or cave area, depending on the relationship between air temperature and the fluctuations of barometric conditions (Perrier et al., 2001; Bourges et al., 2006). Under a steady and confined state the gaseous fluctuations within these isolated areas are only due to the supply from the macrofissural network, which is also in steady state during the wet periods, as well as due to sharp and intense changes of the barometric relationship with the outside atmosphere (i.e.: forced cave ventilation by door opening during tourist visits). In contrast, if an area receives cold outside air with fast transfer times, such as in Sala Nevada chamber, or warm air resulting from tourist visits, pressure-induced temperature changes are hidden by the heat transfer due to advection, and no simple relationship with the pressure-time derivative is observed.

The imbalance of $\mathrm{CO}_{2}$ levels on cave atmosphere caused by the artificial air ventilation (opening of cave entrance), can lead to alteration of the mineral deposition rates and the current growth process of speleothems. Therefore, the conclusions of the present study have a direct application on the protection of the subterranean environment and its application in devising management tools for sustainable cave use. Likewise, understanding the cave air dynamic processes is of crucial importance for using cave stalagmites as an archive of past climate and environmental change, especially regarding to the intra-annual $\mathrm{CO}_{2}$ fluctuations and the key role of karst geochemical processes in the local carbon cycle on short timescales.

\section{ACKNOWLEDGEMENTS}

This research was supported by the Spanish Ministry of Education and Science, project CGL2006-11561/ $\mathrm{BTE}$, in agreement with the Scientific Cooperation between the CSIC and the Department of Agriculture and Environment of the Extremadura Autonomous Region and through FEOGA-ORIENTACION-FEDER funds. Thanks are due to the latter for authorizing the publication of the results. Fernandez-Cortes benefits from the Spanish Ministry of Education and Science Research Programme "Juan de la Cierva" and JAE-Doc Program (CSIC). We are sincerely grateful for all the help given by the cave guides Ana Blázquez and Antonio Baltasar of Castañar cave. We sincerely thank to Dr. Kowalski, Dr. Baldini and other anonymous reviewer for their valuable comments and suggestions for improving the manuscript.

\section{REFERENCES}

Alonso-Zarza A.M. \& Martín-Pérez A., 2008 - Dolomite in caves: Recent dolomite formation in oxic, non-sulfate environments. Castañar Cave, Spain. Sediment. Geol., 205: 160-164.

Badino G., 1995 - Fisica del Clima Sotterraneo. Istituto Italiano di Speleologia. Bologna, $136 \mathrm{p}$.

Baldini J.U.L., Baldini L.M., McDermott F. \& Clipson N., 2006 - Carbon dioxide sources, sinks, and spatial variability in shallow temperate zone caves: evidence from Ballynamintra Cave, Ireland. J. Cave Karst Stud., 68: 4-11.

Baldini J.U.L., McDermott F., Hoffmann D.L., Richards D.A. \& Clipson N., 2008 - Very high-frequency and seasonal cave atmosphere $\mathrm{P}_{-} \mathrm{CO}_{2}$ variability: Implications for stalagmite growth and oxygen isotopebased paleoclimate records. Earth. Planet. Sci. Lett., 272 (1-2): 118-129. 
Barnet I., Prochazka J. \& Skalsky L. 1997 - Do the earth tides have an influence on short-term variations in radon concentration? Radiat. Prot. Dosim., 69 (1): 51-60.

Batiot-Guilhe C., Seidel J.L., Jourde H., Hébrard O. \& Bailly-Comte V., 2007 - Seasonal variations of $\mathrm{CO}_{2}$ and ${ }^{222} \mathrm{Rn}$ in a Mediterranean sinkhole spring (Causse d'Aumelas, SE France). International Journal of Speleology, 36 (1): 51-56.

Bourges F., Mangin A. \& d'Hulst D., 2001 - Carbon dioxide in karst cavity atmosphere dynamics: the example of the Aven d'Orgnac (Ardeche). C. R. Geosci., 333 (11): 685-692.

Bourges F., Genthon P., Mangin A. \& d'Hulst D., 2006 - Microclimates of l'Aven d'Orgnac and other French limestone caves (Chauvet, Esparros, Marsoulas). International Journal of Climatology, 26 (12): 16511670 .

Buck A.L., 1981 - New equations for computing vapor pressure and enhancement factor. J. Appl. Meteorol. Climatol., 20 (12): 1527-1532.

Choppy J., 1990 - Phénomènes Karstiques: Température. Spéléo-Club de Paris, Paris, $2^{\text {éme }}$ edition, $73 \mathrm{p}$.

Cigna A.A., 2004 - Climate of caves. In: Gunn J. (Ed.) - Encyclopedia of Caves and Karst Science. Taylor \& Francis Books, Inc. New York: 228-230.

Cigna A.A., 2005 - Radon in Caves. International Journal of Speleology, 34 (1-2): 1-18.

Craven S.A. \& Smit B.J., 2006 - Radon in caves: Clinical aspects. International Journal of Speleology, 35 (2): 93-101.

CRC (2003) - Handbook of Chemistry and Physics - CRC $84^{\text {th }}$ edition. CRC Press LLC, USA, 2369 p.

Crouzeix C., Le Mouel J.L.,Perrier F. \& Richon P., 2006 - Thermal stratification induced by heating in a nonadiabatic context. Building and Environ., 41: 926939.

Denis A., Lastennet R., Huneau F. \& Malaurent P., 2005 - Identification of functional relationships between atmospheric pressure and $\mathrm{CO}_{2}$ in the cave of Lascaux using the concept of entropy of curves. Geophys. Res. Lett., 32: L05810.

Dinh-Chau N., Chrusciel E. \& Prokólski K., 2005 - Factor controlling measurement of radon mass exhalation rate. J. Environ. Radioact., 82: 363-369.

Faimon J., Stelcl J. \& Sas D., 2006 - Anthropogenic $\mathrm{CO}_{2}-$ flux into cave atmosphere and its environmental impact: A case study in the Cisarska Cave (Moravian Karst, Czech Republic). Sci. Total Environ., 369: 231-245.

Fairchild I.J. \& McMillan E.A., 2007 - Speleothems as indicators of wet and dry periods. International Journal of Speleology, 36 (2): 69-74.

Fernandez-Cortes A., Calaforra J.M. \& Sanchez-Martos F., 2006 - Spatiotemporal analysis of air conditions as a tool for the environmental management of a show cave (Cueva del Agua, Spain). Atmos. Environ., 40 (38): 7378-7394.
Fernandez-Cortes A., Sanchez-Moral S., Cuezva S. \& Abella R., 2009 - Characterization of tracer gas fluctuations in a "low energy" cave (Castañar de Ibor, Spain) using techniques of entropy of curves. International Journal of Climatology, submitted

Hakl J., Csige I., Hunyadi I., Varhegyi A. \& Geczy G., 1996 Radon transport in fractured porous media - Experimental study in caves. Environ. Int., 22: S433-S437.

Hakl J., Hunyadi I., Csige I., Geczy G., Lenart L. \& Varhegyi A., 1997 - Radon transport phenomena studied in karst caves - International experiences on radon levels and exposures. Radiat. Meas., 28 (1-6): 675-684.

Hoyos M., Soler V., Canaveras J.C., Sanchez-Moral S. \& Sanz-Rubio E., 1998 - Microclimatic characterization of a karstic cave: human impact on microenvironmental parameters of a prehistoric rock art cave (Candamo Cave, northern Spain). Environmental Geology, 33 (4): 231242.

Kowalski A.S., Serrano-Ortiz P., Janssens I.A., SanchezMoral S., Cuezva S., Domingo F., Were A. \& AladosArboledas L., 2008 - Can flux tower research neglect geochemical $\mathrm{CO}_{2}$ exchange?. Agric. For. Meteorol., 148 (6-7): 1045-1054.

Lario J., Sanchez-Moral S., Cuezva S., Taborda M. \& Soler V., 2006 - High ${ }^{222}$ Rn levels in a show cave (Castañar de Ibor, Spain): Proposal and application of management measures to minimize the effects on guides and visitors. Atmos. Environ 40: 7395-7400.

Massen F., Dusar M., Loy W. \& Vandenberghe N., 1998 Cave volume computed on the behaviour of a blowing well (Tournai basin, W. Belgium). Terra Nova 10 (3): 131-135.

Perrier F., Morat P. \& Le Mouel J.L., 2001 - Pressure induced temperature variations in an underground quarry. Earth Planet. Sci. Lett., 191 (1-2): 145-156.

Perrier F., Richon P., Crouzeix C., Morat P. \& Le Mouel J.L., 2004 - Radon-222 signatures of natural ventilation regimes in an underground quarry. J. Environ. Radioact., 71 (1): 17-32.

Perrier F., Richon P., Gautam U., Tiwari D.R., Shrestha P. \& Sapkota S.N., 2007 - Seasonal variations of natural ventilation and radon-222 exhalation in a slightly rising dead-end tunnel. J. Environ. Radioact., 97: 220-235.

Richon P., Perrier F., Pili E. \& Sabroux J.C., 2009 Detectability and significance of $12 \mathrm{~h}$ barometric tide in radon-222 signal, dripwater flow rate, air temperature and carbon dioxide concentration in an underground tunnel. Geophys. J. Int., 176: 683-694.

Sanchez-Moral S., Soler V., Canaveras J.C., Sanz-Rubio E., Van Grieken R. \& Gysels K., 1999. Inorganic deterioration affecting the Altamira Cave, N Spain: quantitative approach to wall-corrosion (solutional etching) processes induced by visitors. Sci. Total Environ., 243-244: 67-84.

Spötl C., Fairchild I.J. \& Tooth A.F., 2005 - Cave air control on dripwater geochemistry, Obir Caves (Austria): Implications for speleothem deposition in dynamically ventilated caves. Geochim. Cosmochim. Acta, 69 (10): 2451-2468. 